\title{
ПРИЧИНИ І РЕЗУЛЬТАТИ ПЕРЕГЛЯДУ ОЦІНКИ ПОТЕНЦІАЛУ ВІТРОВИХ ЕЛЕКТРОСТАНЦЙ УКРАЇНИ
}

С.О. Кудря ${ }^{1}$, чл.-кор. НАН України, докт. техн. наук, проф., Н.М. Мхітарян ${ }^{1}$, чл.-кор. НАН України, докт. техн. наук, проф., Б.Г. Тучинський ${ }^{1}$, канд. екон. наук, ст. наук. співроб., О.О. Рєпкін ${ }^{2}$, голова наглядової ради ТОВ Токмак Солар Енерджі, голова енергетичної асоціації «Українська Воднева Рада», І.В. Іванченко ${ }^{1}$, К.В. Петренко ${ }^{1}$.

${ }^{1}$ Інститут відновлюваної енергетики НАН України, 02094, вул. Гната Хоткевича, 20А, м. Київ, Україна.

${ }^{2}$ Громадська спілка «Енергетична асоціація «Українська воднева рада», 01015, вул. Лаврська, 16, м. Київ, Україна.

Мета статті - сучасна оцінка вітропотенціалу Украйни $i$ перспектив розвитку вітроенергетики. Попит на електроенергію має сталу тенденцію до зростання, а пропозиція електроенергії теплових і атомних електростанцій обмежується, головним чином, вичерпаністю світових запасів відповідних енергоносїв $і$ їх нерівномірним розподілом між краӥнами. Останне створюе політичну і економічну залежність країн-імпортерів енергоносіїв від краӥн, щзо енергоносії експортують. За прогнозом Міжнародного енергетичного агентства (IEA), в СС сума інвестицій у вітроенергетику в період 2014-2035 рр. становитиме 727 \$млрд і буде найвищою серед галузей електроенергетики - в 1.8 рази вищою, ніж в ТЕС і АЕС разом (400 \$млрд). За останній час відбулись суттєві прогресивні зміни кількісних і якісних параметрів генераиіі електроенергї ВЕС, а саме: подовжились лопаті вітрових електроустановок (ВЕУ); збільшились висоти веж ВЕУ. Дослідження вітрових потоків показали, що вертикальні профілі вітру фактично є більш чутливими до збільшення висоти над землею, ніж припускалось раніше. Крім того, має місце подвоєння номінальної потужності ВЕУ, за рахунок чого зменшуються як площі покриття ВЕС, так і питомі витрати землі, вилученої з сільськогосподарського використання. Якщо у попередніх дослідженнях придатними для ВЕС визначались лите зони Причорномор'я $і$ Приазов'я, то в результаті спільної дї̈ перелічених факторів значні території в інших регіонах Украӥни, що раніше вважались непридатними для розміщення економічно ефективних ВEC, перейшли до категорії перспективних. В даній статті представлено географічний підхід до оцінювання вітропотенціалу територій Украйни. Цей підхід є значно простіший, потребує значно менше витрат часу і коштів, ніж відомі підходи. Бібл. 6, табл. 4, рис. 8.

Ключові слова: вітроенергетика, технічно-досяжний вітропотенціал, вітрова електростанція, географічний підхід, зонування, потенціал встановленої потужності ВЕС.

\section{POTENTIAL OF UKRAINE'S WIND POWER PLANTS REASSESSMENT. THE REASONS AND THE RESULTS}

S. Kudrya ${ }^{1}$, corresponding member of NAS, doctor of technical sciences, professor, N. Mkhitaryan ${ }^{1}$, corresponding member of NAS, doctor of technical sciences, professor, B. Tuchynskyi ${ }^{1}$, candidate of economic sciences, senior researcher, A. Riepkin ${ }^{2}$, chairman of the board of the company Tokmak Solar Energy, head of the Energy Association «Ukrainian Hydrogen Council», I. Ivanchenko ${ }^{1}$, K. Petrenko ${ }^{1}$.

${ }^{1}$ Institute of Renewable Energy of the National Academy of Sciences of Ukraine, 02094, 20A Hnata Khotkevycha St., Kyiv, Ukraine.

${ }^{2}$ Energy Association «Ukrainian Hydrogen Council», 01015, 16 Lavrska St., Kyiv, Ukraine.

Purpose of the article is to make a nowadays wind energy potential assessment and to study the prospects for the development of wind energy. Demand for electricity has a steady upward trend. The electricity supply of thermal and nuclear power plants is mainly limits by the depletion of the world's energy resources and their uneven distribution between countries. The last creates the political and economic dependence of energy importing countries on energy exporting ones. According to the International Energy Agency (IEA), wind energy investments in the EU in 2014-2035 will be \$ 727 billion and will be the highest among the power industries - 1.8 times higher than in TPPs and NPPs together (\$400 billion). Recently, there have been significant progressive changes in the quantitative and qualitative parameters there of wind power generation: the wind blades of the wind turbines extended; the heights of the wind turbines increased. Studies of the wind flows have shown that the vertical wind profiles are actually more sensitive to the elevation above the ground than previously thought. Besides, there is a doubling of the wind turbines' nominal capacity, thereby reducing both the area of coverage by wind turbines and the specific consumption of land withdrawn from agricultural use. In previous studies, only areas near the Black Sea and the Sea of Azov were identified as suitable for the wind farms, as a result of the combined effect of the above factors, significant territories in other regions of Ukraine that were previously considered as unfit for the deployment of cost-effective wind farms have been classified as promising. This article presents a geographic approach to the wind potential of Ukraine assessment. This approach provides sufficient accuracy, is much simpler, requires significantly less time and cost than the known approaches. Ref. 6, tabl. 4, fig. 8. Keywords: wind power, technically achievable wind potential, wind power plant, geographical approach, zoning, installed capacity of wind power plant. 


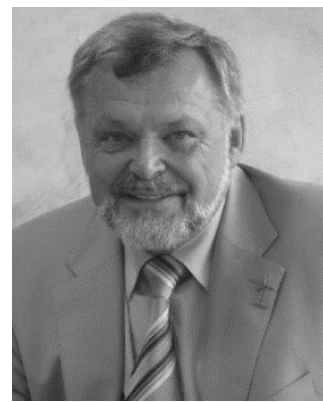

C.O. Кудря

S. Kudria

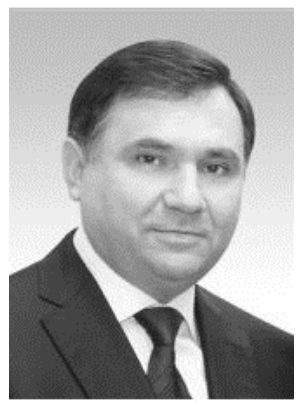

H.M. Мхітарян

N. Mkhitaryan

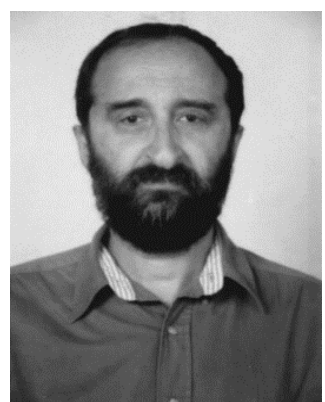

Б.Г. Тучинський

B. Tuchynskyi

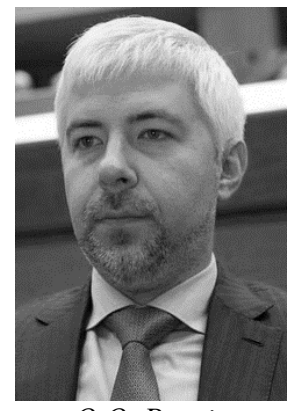

O.O. Репкін

A. Riepkin
Відомості про автора: Директор Інституту відновлюваної енергетики НАН України, член-кореспондент НАН України, професор, доктор технічних наук.

Освіта: Національний технічний університет України «Київський політехнічний інститут ім. І. Сікорського», хіміко-технологічний факультет.

Наукова сфера: відновлювані джерела енергії, акумулювання енергії, енергоефективні технології, воднева енергетика.

Публікації: 376.

ORCID: 0000-0002-4798-6853

Контакти: тел./факс: +38 (044) 206-28-09

e-mail: renewable@ukr.net

Відомості про автора: Почесний директор Інституту відновлюваної енергетики НАН України, член-кореспондент НАН України, професор, доктор технічних наук.

Освіта: Єреванський політехнічний інститут за спеціальністю «Виробництво будівельних виробів і конструкцій».

Наукова сфера: відновлювані джерела енергії, енергоефективні технології, комплексні енергетичні системи.

Публікації: понад 200.

ORCID: 0000-0002-5918-4532

Контакти: тел./факс: +38 (044) 206-28-09

e-mail: renewable@ukr.net

Відомості про автора: старший науковий співробітник відділу вітроенергетики Інституту відновлюваної енергетики НАН України, старший науковий співробітник, кандидат економічних наук.

Освіта: Київський національний університет ім. Тараса Шевченка, механіко-математичний факультет.

Наукова сфера: прикладна математика, обчислювальні методи в математиці, математична статистика, математичні моделі $\mathrm{i}$ методи в економіці, інвестиційний аналіз, вітроенергетика.

Публікації: 117.

ORCID: 0000-0002-5180-6886

Контакти: тел./факс: +38 (044) 206-28-09

e-mail: bortu77@yahoo.com

Відомості про автора: Голова наглядової ради ТОВ Токмак Солар Енерджі, Голова енергетичної асоціації «Українська Воднева Рада». Освіта: закінчив у 2002 році Національну академію Служби безпеки України за спеціальністю «Правознавство».

Наукова сфера: сонячна енергетика, воднева енергетика.

Публікації: 6 .

ORCID: 0000-0002-3448-6729

Контакти: +38068 8993399

e-mail: a.riepkin@me.com
Author information: director of the Institute of Renewable Energy of NAS of Ukraine, corresponding member of NAS of Ukraine, professor, doctor of technical sciences. Education: National Technical University of Ukraine "Igor Sikorsky Kyiv Polytechnic Institute", Faculty of Chemical Technology. Research area: renewable energy sources, energy storage, energy efficient technologies, hydrogen energy.

Publications: 376 .

ORCID: 0000-0002-4798-6853

Contacts: tel./fax: +38 (044) 206-28-09

e-mail: renewable@ukr.net

Author information: Honorary Director of the Institute of Renewable Energy of NAS of Ukraine, corresponding member of NAS of Ukraine, professor, doctor of technical sciences. Education: Yerevan Polytechnic Institute, specialty "Production of building products and structures".

Research area: renewable energy sources, energy efficient technologies, hybrid renewable energy systems.

Publications: more than 200.

ORCID: 0000-0002-5918-4532

Contacts: tel./fax: +38 (044) 206-28-09

e-mail: renewable@ukr.net

Author information: senior researcher at wind energy department at Institute of Renewable Energy of NAS of Ukraine, senior researcher, candidate of economic sciences.

Education: Taras Shevchenko National University of Kyiv, Faculty of Mechanics and Mathematics.

Research area: applied mathematics, computational methods in mathematics, mathematical statistics, mathematical models and methods in economics, investment analysis, wind power.

Publications: 117.

ORCID: 0000-0002-5180-6886

Contacts: tel./fax: +38 (044) 206-28-09

e-mail: bortu77@yahoo.com

Author information: Chairman of the Board of the company Tokmak Solar Energy, Head of the Energy Association «Ukrainian Hydrogen Council».

Education: graduated from the National Academy of Security Service of Ukraine in 2002 with a degree in Law.

Research area: solar power, hydrogen power.

Publications: 6 .

ORCID: 0000-0002-3448-6729

Contacts: +380688993399

e-mail: a.riepkin@me.com 


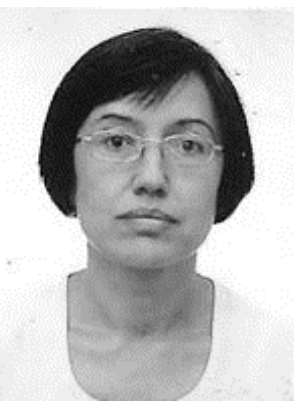

I.B. Іванченко

I. Ivanchenko

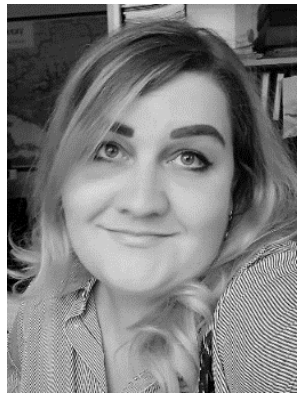

К.В. Петренко

K. Petrenko
Відомості про автора: головний технолог відділу вітроенергетики Інституту відновлюваної енергетики НАН України.

Освіта: Київський національний університет технологій та дизайну, інженерно-

економічний факультет.

Наукова сфера: вітроенергетика, оцінка вітроенергетичного потенціалу, економічна ефективність інвестицій в будівництво вітрових електростанцій.

Публікації: 30 .

ORCID: 0000-0002-5083-4180

Контакти: тел./факс: +38 (044) 206-28-09

e-mail: mntcwind@gmail.com

Відомості про автора: головний технолог відділу вітроенергетики Інституту відновлюваної енергетики НАН України, магістр метеорології та кліматології Освіта: Київський національний університет імені Тараса Шевченка, географічний факультет, кафедра метеорології та кліматології.

Наукова сфера: метеорологія, кліматологія, картографія, вітроенергетика.

Публікації: 11.

ORCID: 0000-0002-2322-9030

Контакти: тел.: +38 (067) 129-07-43

e-mail: KaterynkaPetrenko@gmail.com
Author information: chief technologist at wind energy department at Institute of Renewable Energy of NAS of Ukraine.

Education: Kiev National University of Technology and Design, Faculty of Engineering and Economics.

Research area: wind energy, assessment of wind energy potential, economic efficiency of investments in the construction of wind power plants.

Publications: 30 .

ORCID: 0000-0002-5083-4180

Contacts: tel./fax: +38 (044) 206-28-09

e-mail: mntcwind@gmail.com

Author information: chief technologist of Wind Energy Department, Institute of Renewable Energy of NAS of Ukraine,

Master Degree (Meteorology and Climatology).

Education: Taras Shevchenko National

University, Department of Meteorology and Climatology.

Research area: meteorology, climatology, cartography, wind power.

Publications: 11

ORCID: 0000-0002-2322-9030

Contacts: тел.: +38 (067) 129-07-43

e-mail: KaterynkaPetrenko@gmail.com
Перелік використаних позначень та скорочень:

$\mathrm{EC}-$ Свропейський Союз;

ВEC - вітрова електростанція;

ТЕС -теплова електростанція;

AEC - атомна електростанція;

МC - метеостанція;

ВЕУ - вітрова електроустановка;

Вступ. Електроенергія є товаром, специфіка якого полягає у наступному:

1. Попит на електроенергію має сталу тенденцію до зростання.

2. Пропозиція електроенергії теплових i атомних електростанцій обмежується, головним чином, вичерпаністю світових запасів відповідних енергоносіїв і їх нерівномірним розподілом між країнами.

Останнє створює політичну i економічну залежність країн-імпортерів енергоносіїв від країн, що енергоносії експортують. Тому, починаючи з 70-х років XX ст., держави багатьох країн світу запровадили законодавчу і фінансову підтримку розвитку відновлюваної енергетики, зокрема, вітроенергетики. Ця технологія здійснює генерацію електроенергії шляхом перетворювання енергії вітру без закупівлі імпортних енергоносіїв.

На початку XXI ст. в розвитку світової вітроенергетики відбулися радикальні зміни. Ця
КВНП - коефіцієнт використання номінальної потужності; КВВП - коефіцієнт використання встановленої потужності; ТДВП - технічно-досяжний вітропотенціал; GIS - геоінформаційна система;

МВТ - мегават;

ГВт -гігават. галузь стала першою $з$ галузей відновлюваної енергетики, що увійшла до складу “великої” електроенергетики. Деякі підсумки цього процесу представлено в табл. 1 [1].

Таблиця 1. Результати розвитку вітроенергетики Свропи за 2018 р.

Table 1. European Wind Energy Development Results 2018

\begin{tabular}{|l|c|}
\hline \multicolumn{1}{|c|}{ Країна } & $\begin{array}{c}\text { Частка вітроенергетики в загальній } \\
\text { генерації електроенергії, \% }\end{array}$ \\
\hline Данія & 41 \\
\hline Ірландія & 27 \\
\hline Португалія & 24 \\
\hline Німеччина & 21 \\
\hline СС & 14 \\
\hline
\end{tabular}

На сьогодні вітроенергетика $\epsilon$, i буде в перспективі, найбільш привабливою для інвесторів галуззю європейської електроенергетики. Так, за прогнозом [2] авторитетного Міжнародного енергетичного агентства (IEA), в ЄC сума інвестицій у 
вітроенергетику в період 2014-2035 pp. становитиме 727 \$млрд і буде найвищою серед галузей електроенергетики - в 1.8 рази вищою, ніж в ТЕС і АЕС разом (400 \$млрд).

Оцінки минулих років і необхідність їх перегляду. Як зазначалось в [3], для обгрунтування стратегічних рішень щодо розвитку електроенергетики, виникла необхідність отримання оцінок максимальної сумарної потужності технічно можливих i економічно ефективних вітрових електростанцій (BEC), створених на території кожної країни. В 1990-2005 pp. відповідні дослідження ТДВП України здійснювались рядом закордонних організацій i компаній. Отримані оцінки становили 14-24 ГВт [3].

Але за час, що минув, відбулись суттєві прогресивні зміни кількісних i якісних параметрів генерації електроенергії ВЕС, а саме:

1. Подовжились лопаті ВЕУ.

2. Збільшились висоти веж ВЕУ.

3. Дослідження вітрових потоків показали, що вертикальні профілі вітру фактично є більш чутливими до збільшення висоти над землею, ніж припускалось раніше.

В табл. 2 в якості прикладу подано результати відповідних розрахунків за даними спостережень швидкості вітру на типовій українській МС «Біла Церква» (рис. 1) протягом валідного періоду 1988-2009 pр.

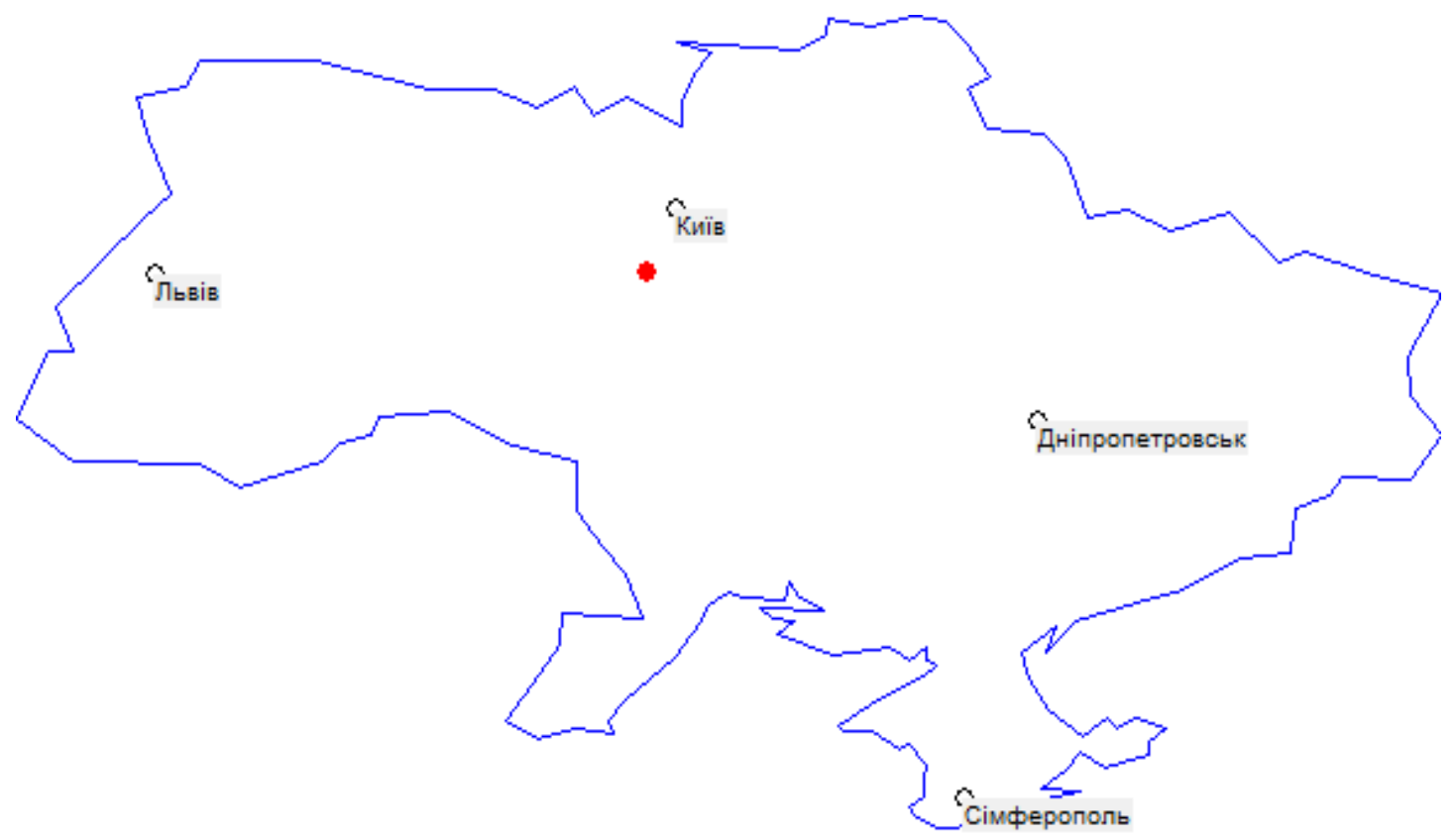

Рис. 1. Локалізація МС «Біла Церква».

Fig. 1. Localization of Weather Station "Bila Tserkva".

Таблиця 2. Вплив факторів на КВНП ВЕУ.

Table 2. Factors influence on Capacity Factor of wind turbines.

\begin{tabular}{|l|c|c|c|c|}
\hline \multicolumn{1}{|c|}{ Модель ВЕУ } & $\begin{array}{c}\text { Діаметр } \\
\text { вітроколеса, } \mathbf{M}\end{array}$ & $\begin{array}{c}\text { Висота осі ротора, } \\
\text { м }\end{array}$ & Параметр Хеллмана & КВНП \\
\hline Vestas V80-2.0 & 80 & 60 & 0.14 & 0.125 \\
\hline & 80 & 60 & 0.20 & 0.171 \\
\hline & 80 & 100 & 0.14 & 0.152 \\
\hline Vestas V110-2.0 & 80 & 100 & 0.20 & 0.221 \\
\hline & 110 & 100 & 0.14 & 0.265 \\
\hline
\end{tabular}


Аналіз табл. 2 засвідчує, що спільна дія трьох зазначених факторів призводить до збільшення виробітку електроенергії ВЕУ втричі без зміни потужності ВЕУ, що $\epsilon$ основним чинником підвищення ТДВП. Крім того, має місце подвоєння номінальної потужності ВЕУ, за рахунок чого зменшуються як площі покриття $\mathrm{BEC}$, так і питомі витрати землі, вилученої 3 сільськогосподарського використання.

Якщо у вищезгаданих попередніх дослідженнях придатними для ВЕС визначались лише зони Причорномор'я i Приазов'я, то в результаті спільної дії перелічених факторів значні території в інших регіонах України, що раніше вважались непридатними для розміщення економічно ефективних $\mathrm{BEC}$, перейшли до категорії перспективних.

В статті [3] представлено аналітичний огляд удосконаленої методики оцінювання ТДВП Європейського агентства 3 охорони довкілля (EEA) [4] 3 використанням сучасних засобів геоінформаційних систем (GIS), баз даних характеристик вітру (в тому числі - дані реаналізу), баз даних технічних параметрів ВЕУ, що дозволило зробити отримані оцінки більш обгрунтованими.

Міжнародне агентство 3 відновлюваних джерел енергії (IRENA) використало зазначену методику [4] для отримання нових уточнених оцінок вітропотенціалу країн південно-східної
Європи, зокрема, для України [5]. Загальна встановлена потужність наземних (офшорних) ВЕС в Україні оцінюється в [5] в 320 ГВт. В [6] аналогічне дослідження показало відповідну оцінку 393 ГВт.

Зазначені вище зміни параметрів генерації електроенергії ВЕС та методик оцінювання ТДВП вимагають перегляду підходів.

В даній статті представлено географічний підхід до оцінювання ТДВП територій України. Цей підхід забезпечує точність оцінки ТДВП, є значно простіший, потребує значно менше витрат часу і коштів, ніж підхід, викладений в $[2,6]$.

Географічне зонування - основа оцінки вітропотенціалу України. Оцінку потенціалу встановленої потужності українських ВЕС здійснено на основі географічного підходу. Як відомо, виробіток електроенергії ВЕС суттєво залежить від природних умов розташування площадки BEC. Територія суходолу України за природними умовами поділяється на чотири природні зони (рис. 2).

Для кожної природної зони $є$ притаманними свої однорідні географічні умови, зокрема, умови вітроутворення. В той же час, інші умови, природні і антропогенні, що мають значення для розміщення ВЕС, всередині кожної природної зони можуть варіюватись.

Характерні ландшафти природних $30 \mathrm{H}$ України представлено на рис. 3-7.

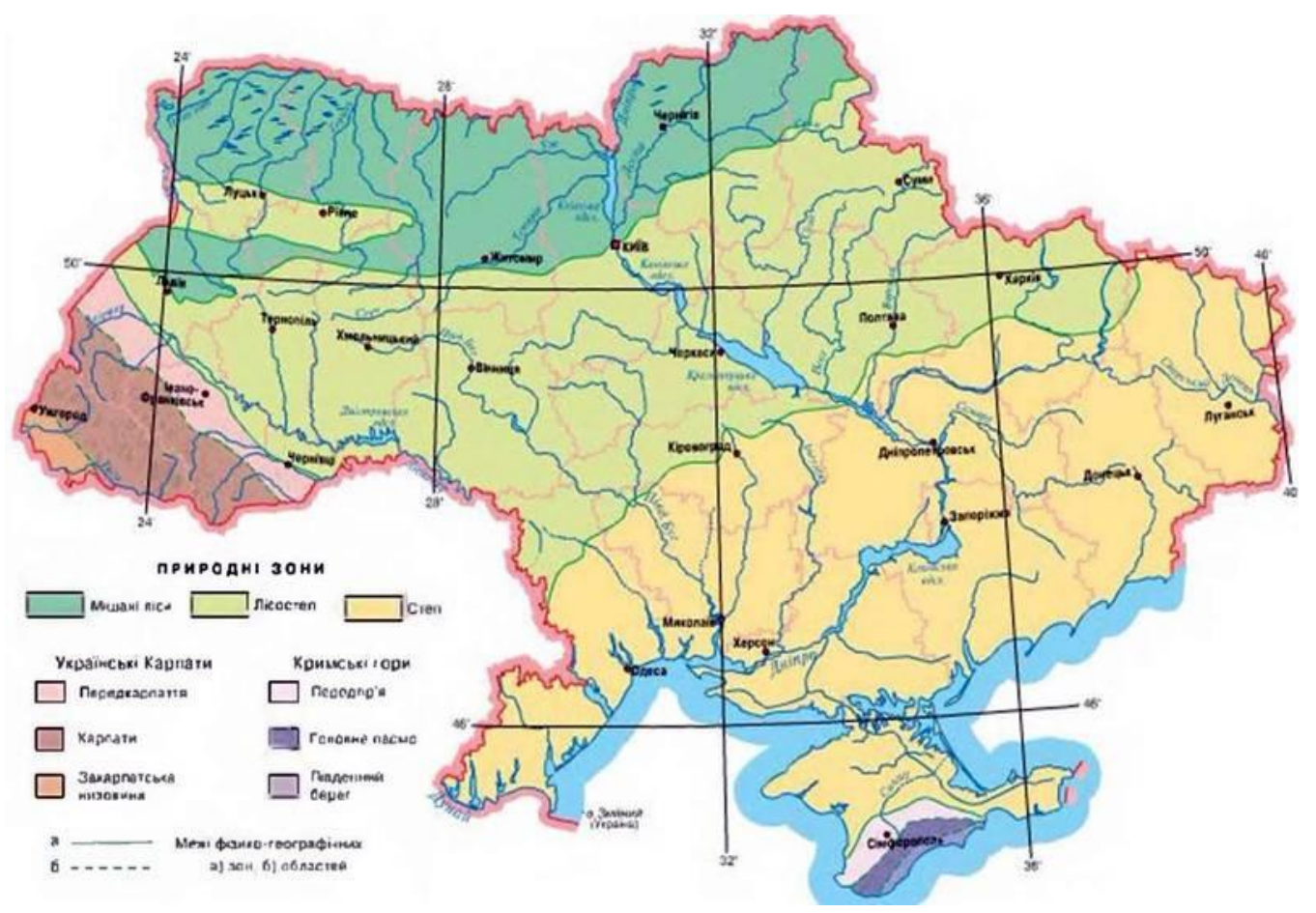

Рис. 2. Карта природних зон України [7].

Fig. 2. Map of natural areas of Ukraine [7]. 


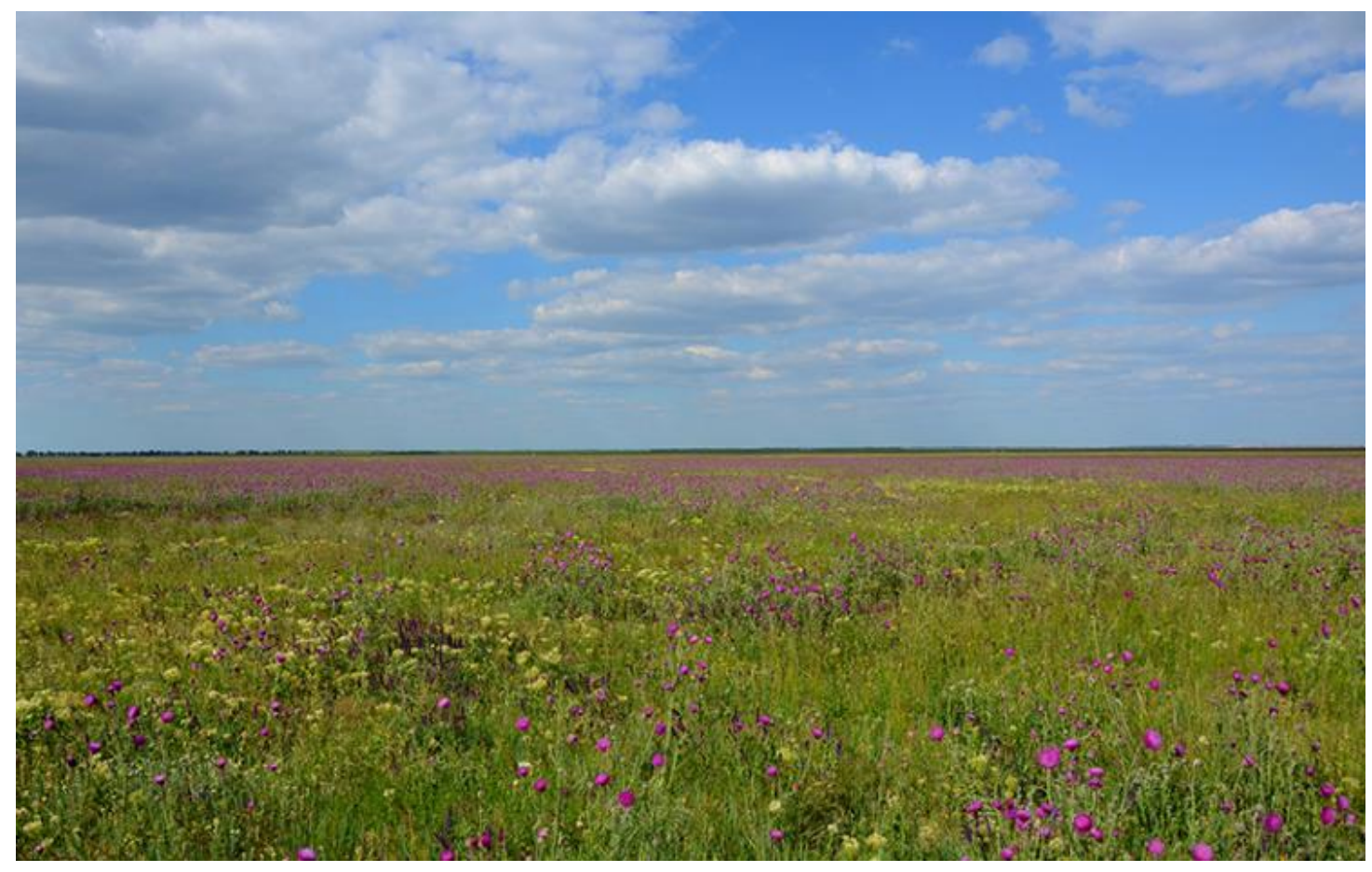

Рис. 3. Український степ.

Fig. 3. Ukrainian steppe.

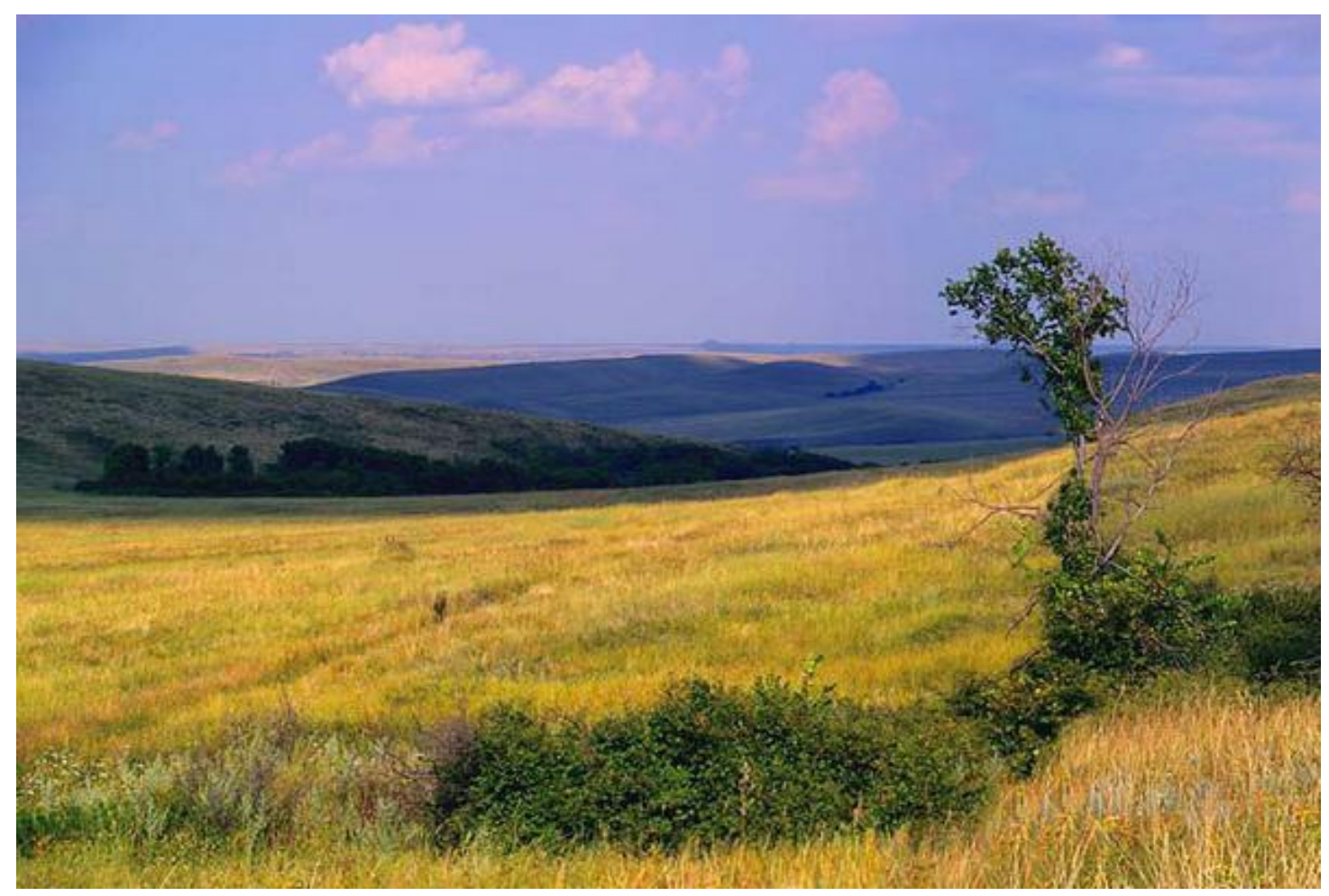

Рис. 4. Український лісостеп.

Fig. 4. Ukrainian forest-steppe. 


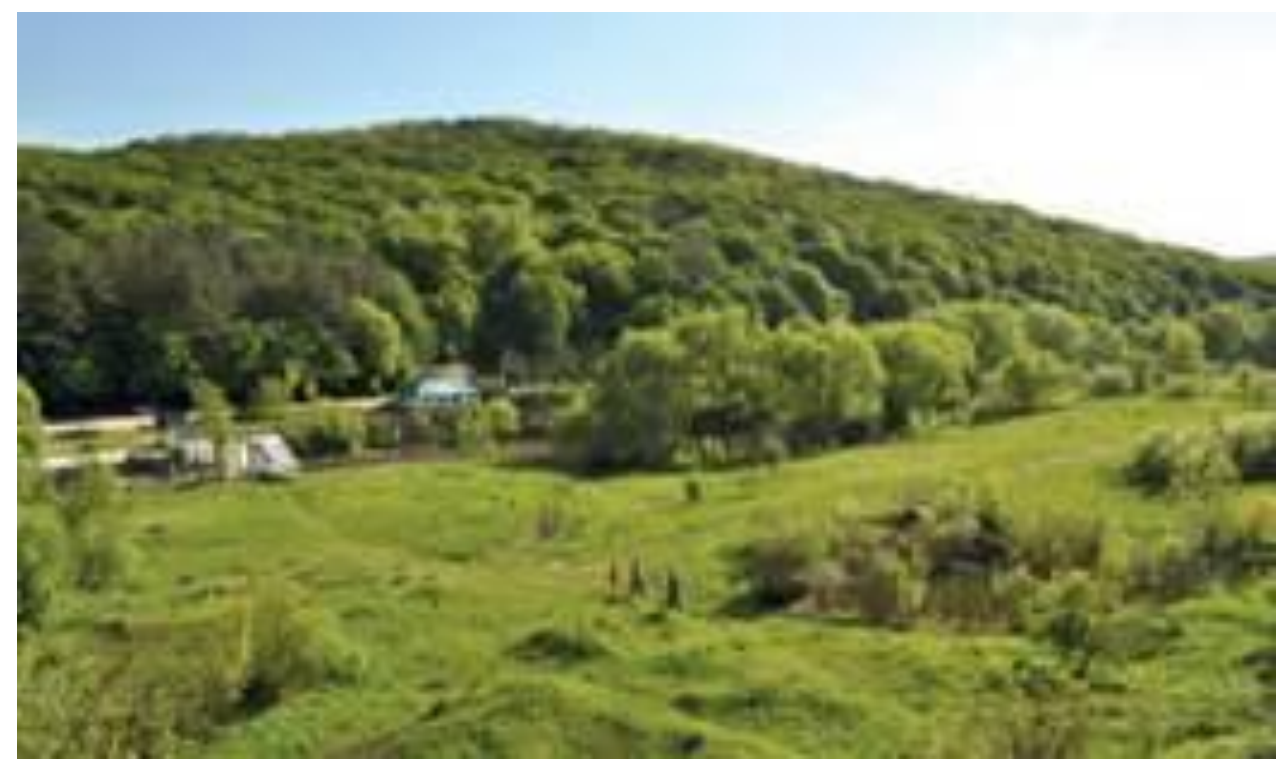

Рис. 5. Мішані ліси України.

Fig. 5. Mixed forests of Ukraine.

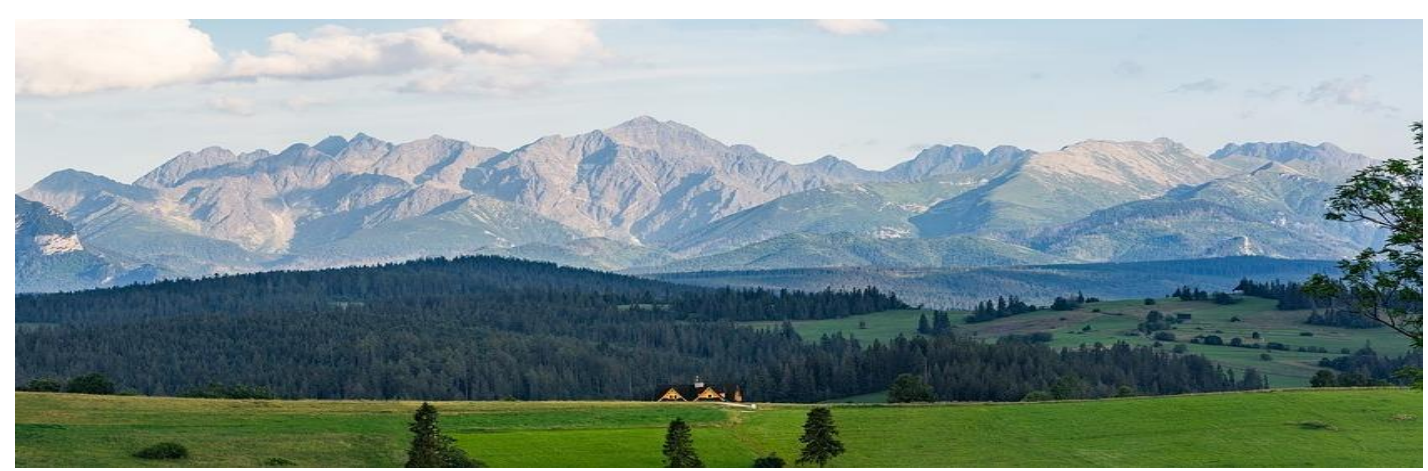

Рис. 6. Українські Карпати.

Fig. 6. Ukrainian Carpathian Mountains.

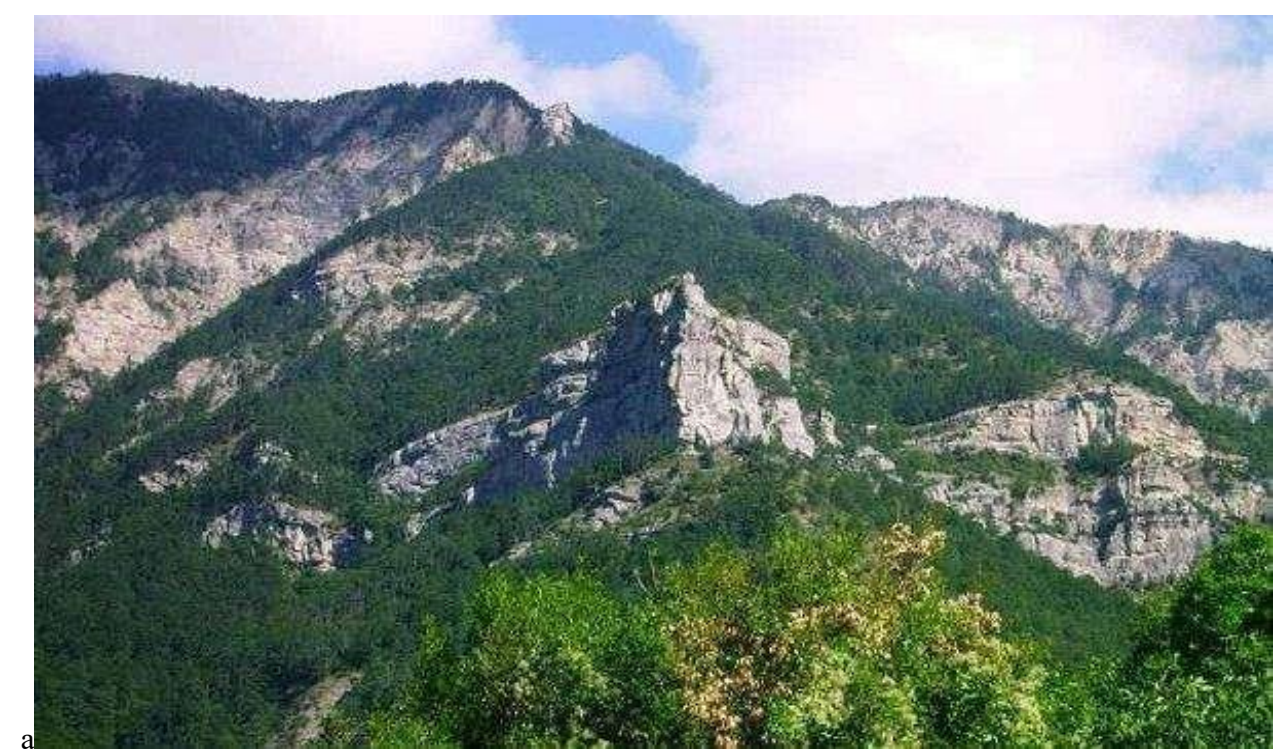

Рис. 7. Кримські гори.

Fig. 7. Crimean mountains. 
3 рис. 3-7 видно, що найскладнішими для будівництва ВЕС є гірські райони. Будівництво ВEC в цих районах потребує суттєвого збільшення витрат часу i коштів на вибір площадок для ВЕС, доставку ВЕУ $\mathrm{i}$ кранів, прокладання шляхів і ліній електропередачі, обслуговування тощо.

3 інших причин малопривабливою для будівництва ВЕС є лісова зона. Ліси є природніми перешкодами вітровим потокам. Дерева, навіть суттєво нижчі нижнього краю вітроколеса ВЕУ, збільшують турбулентність відповідного вітрового потоку, що зменшує виробіток електроенергії ВЕУ і прискорює іiі знос.
Територія зони лісостепу, що залишається після вилучення лісових ділянок і перешкод антропогенного характеру, є цілком придатною для реалізації економічно ефективних інвестиційних проектів ВЕС.

Найбільш привабливою для реалізації таких проектів є степова зона. Сильні вітри в холодну пору року, в теплу пору року зменшують свою силу, але компенсують це зменшення додатковими локальними вітрами - бризами. Наявність в степовій зоні потужних морських портів і мереж автошляхів спрощують вирішення проблем логістики.

На рис. 8 подано дані щодо нормативногрошової оцінки землі для областей України [8].

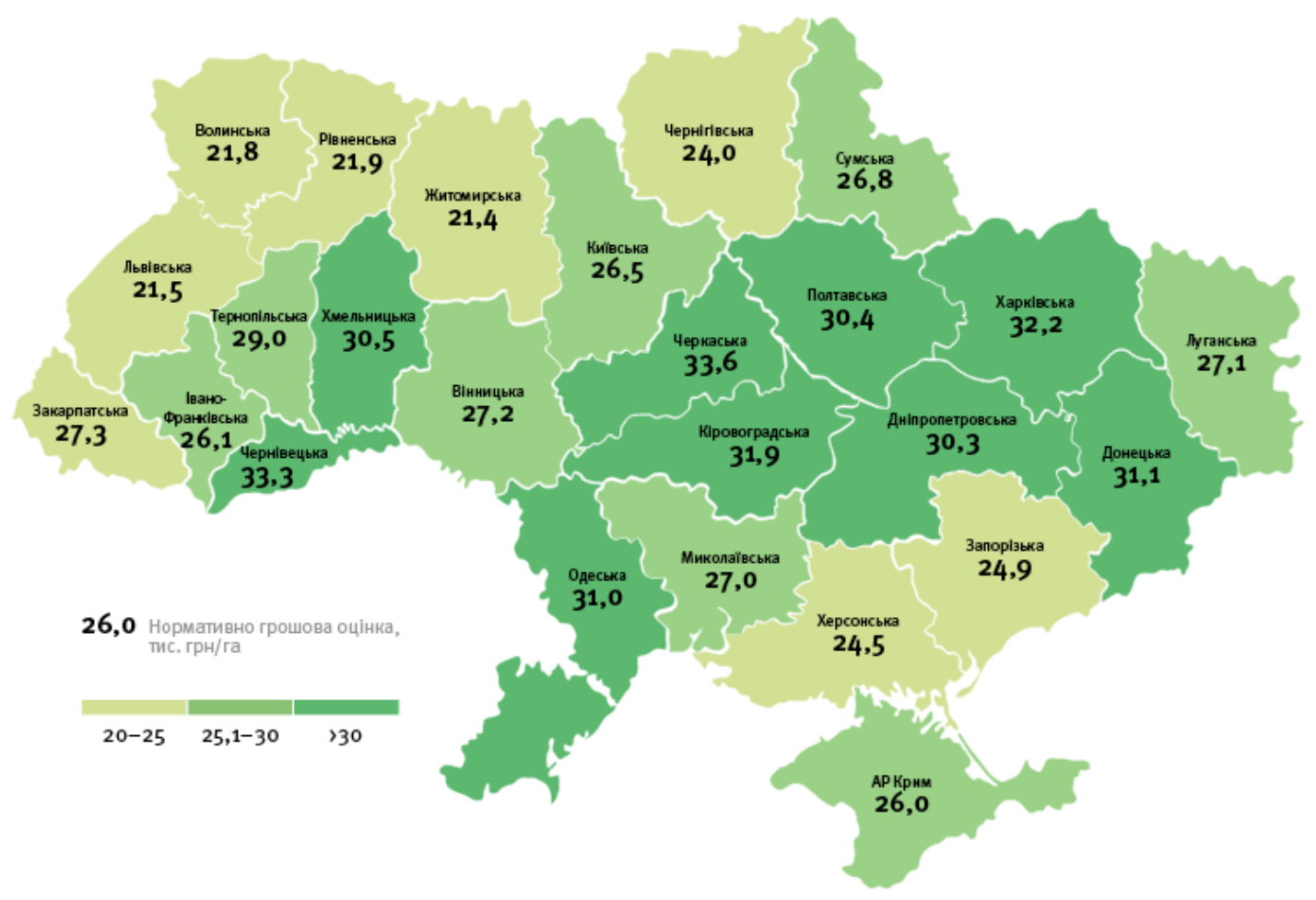

Рис. 8. Карта розподілу нормативно-грошової оцінки вартості землі сільськогосподарського призначення.

Fig. 8. Map of the distribution of the regulatory monetary value of agricultural land. 
3 порівняння карт на рис. 2 i на рис. 8, для землеробства, але цілком придатних i випливає, що землі п'яти регіонів степової зони є економічно вигідних для ВЕС, становить 10000 тис низько продуктивними $\mathrm{i}$, як наслідок, низько га $=100$ тис кв км.

вартісними. Це - АР Крим і області - Україна має потужні ресурси вітрової Миколаївська, Херсонська, Запорізька і Луганська. офшорної енергії (рис. 9).

Загальна площа цих земель, низько продуктивних

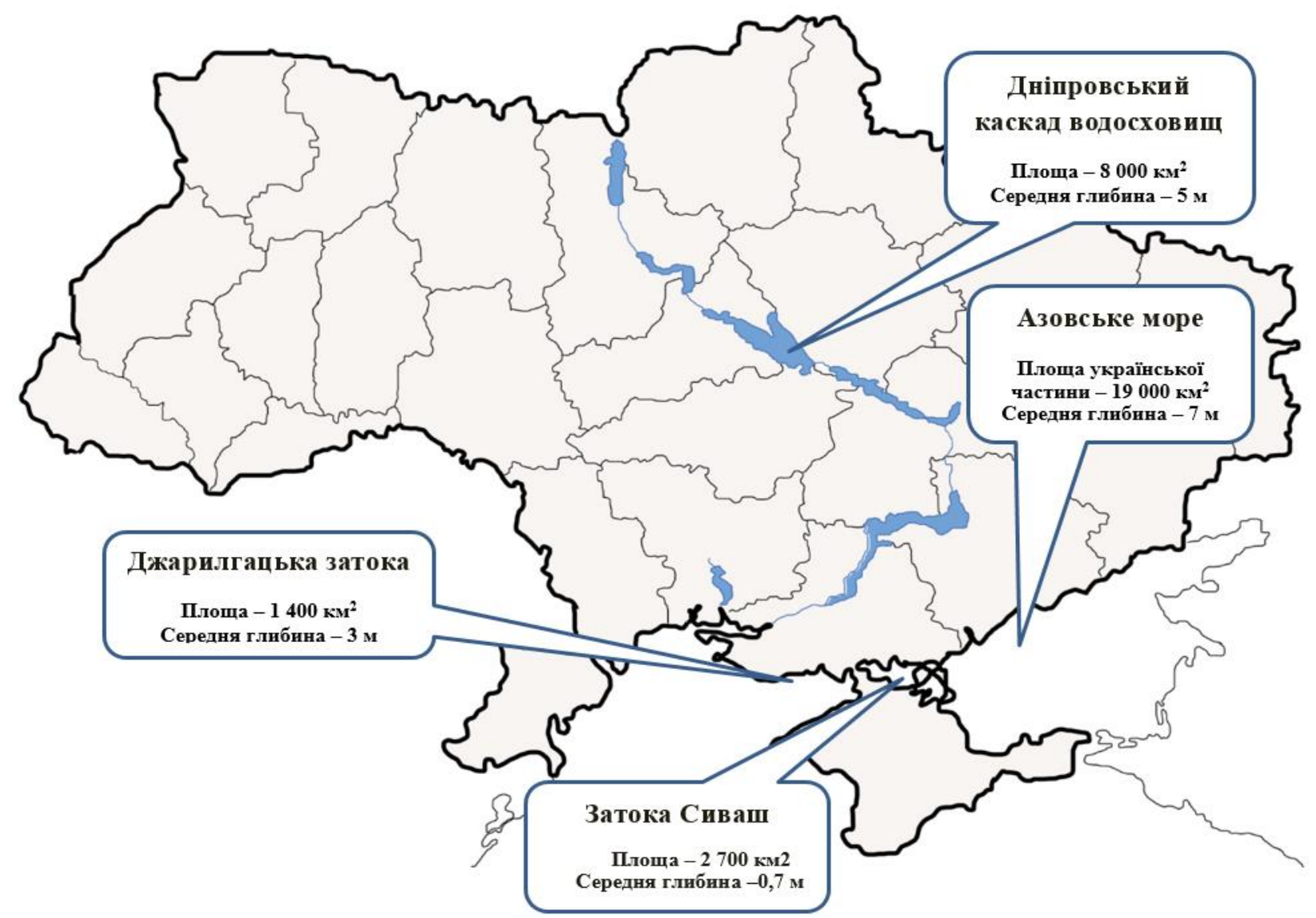

Рис. 9. Карта основних акваторій території України.

Fig. 9. Map of the main water areas of Ukraine.

Мілководні території акваторій Азовського та Чорного морів, Дніпровського каскаду i Дністровських водосховищ, затоки Сиваш та ін. дозволяють будувати економічно ефективні офшорні BEC.

Оцінювання потенціалу потужності ВЕС України.

Припущення щодо значень параметрів:

Номінальна потужність ВЕУ - 3 МВт.

Щільність розстановки ВЕУ - 4 ВЕУ на 1 кв км території.

Мінімальний КВВП-нетто:

-0.31 для оншорних ВEC;

-0.45 для офшорних ВЕС.
Питоме землевідведення:

- $\quad$ фундамент 3 площадкою - 0.3 га/ВЕУ;

- ПС -0.2 га/ВЕУ;

- дороги -0.5 га/ВЕУ;

- РАЗОМ - 1.0 га/ВЕУ (за да-

ними фактичних витрат землі для проектів ВЕС на базі сучасних моделей ВЕУ).

Результати розрахунків потенціалу потужності ВЕС в Україні.

В табл. 3-4 подано результати розрахунків потенціалу потужності наземних (оншорних) i офшорних ВЕС в Україні. 
Таблиця 3. Початкові дані і результати оцінювання потенціалу встановленої потужності наземних (оншорних) ВЕС на території України.

Table 3. Initial data and results of the evaluation of potential installed capacity of land (onshore) wind farm in Ukraine.

\begin{tabular}{|c|c|c|c|c|c|c|c|}
\hline № & $\begin{array}{c}\text { Природна } \\
\text { зона }\end{array}$ & $\begin{array}{l}\text { Площа, } \\
\text { тис кв км }\end{array}$ & $\begin{array}{c}\text { Експертна } \\
\text { оцінка частки } \\
\text { території зони, } \\
\text { придатної } \\
\text { для ВЕС, } \\
\%\end{array}$ & $\begin{array}{c}\text { Площа } \\
\text { території } \\
\text { для ВЕС, } \\
\text { тис кв км }\end{array}$ & $\begin{array}{c}\text { Кількість } \\
\text { ВЕУ, } \\
\text { Тис штт }\end{array}$ & $\begin{array}{c}\text { Потенціал } \\
\text { потужності } \\
\text { ВЕС, } \\
\text { ГВТ }\end{array}$ & $\begin{array}{c}\text { Площа } \\
\text { відведеної } \\
\text { землі, } \\
\text { тис га }\end{array}$ \\
\hline 1 & Степ & 240 & 10.0 & 24.0 & 96.0 & 288 & 96.0 \\
\hline 2 & Лісостеп & 202 & 5.0 & 10.0 & 40.0 & 120 & 40.0 \\
\hline 3 & Лic & 113 & 1.9 & 2.2 & 8.6 & 26 & 8.6 \\
\hline 4 & Гори & 45 & 0.7 & 0.3 & 1.3 & 4 & 1.3 \\
\hline 5 & Разом & 600 & 6.1 & 36.5 & 145.9 & 438 & 145.9 \\
\hline
\end{tabular}

Таблиця 4. Вихідні параметри і результати оцінювання потенціалу встановленої потужності офшорних ВЕС на території України.

Table 4. Input parameters and results of the evaluation of potential installed capacity of offshore wind farms in Ukraine.

\begin{tabular}{|l|l|c|c|c|c|c|}
\hline \multirow{2}{*}{ № } & \multicolumn{1}{|c|}{ Акваторія } & $\begin{array}{c}\text { Площа } \\
\text { мілководдя, } \\
\text { кв км }\end{array}$ & $\begin{array}{c}\text { Експертна оцінка } \\
\text { частки території } \\
\text { зони, придатної } \\
\text { для ВЕС, } \\
\text { \% }\end{array}$ & $\begin{array}{c}\text { Площа } \\
\text { для ВЕС, } \\
\text { кв км }\end{array}$ & $\begin{array}{c}\text { Щільність } \\
\text { розстановки, } \\
\text { МВт/кв км }\end{array}$ & $\begin{array}{c}\text { Потужність } \\
\text { ВЕС, } \\
\text { ГВт }\end{array}$ \\
\hline 1 & $\begin{array}{l}\text { Азовське та Чорне } \\
\text { море (укр.) }\end{array}$ & 19000 & 30 & 5700 & 35 & 199.5 \\
\hline 2 & Залив Сиваш & 2500 & 25 & 625 & 30 & 18.8 \\
\hline 3 & Дніпровський каскад & 6888 & 15 & 1033 & 25 & 25.8 \\
\hline 4 & Лимани & 1500 & 15 & 225 & & 25 \\
\hline $\mathbf{5}$ & Разом & $\mathbf{2 9 8 8 8}$ & $\mathbf{2 5}$ & $\mathbf{7 5 8 3}$ & & $\mathbf{2 4 9 . 7}$ \\
\hline
\end{tabular}

Висновки. 3 поданих в табл. 3-4 даних випливає, що географічні умови території суходолу України дозволяють побудувати 438 ГВт економічно ефективних ВЕС на базі сучасних моделей ВЕУ трьохмегаватного класу. Разом 3 потенціалом офшорних ВЕС це становитиме $\quad 438+250=688$ ГВТ середньозваженою нижньою границею КВВПнетто 0.36. Відповідний річний виробіток електроенергії становитиме майже 2200 млрд кВт·год, що більш, ніж вдесятеро, перевищує річне поточне споживання електроенергії в Україні.

1. Ветроэнергетика Европы: официальные итоги 2018 года.[Електронний ресурс].URL: https://elektrovesti.net/64642 _vetroenergetika-evropy-ofitsialnye-itogi-2018-goda.

2. World Energy Investment Outlook. Special Report. OECD/IEA. 2014. 190 p. [Електронний pecypc]. URL: https://www.iea.org/publications/freepublications/publicati on/WEIO2014.pdf.

3. Кудря С.О., Тучинський Б.Г., Іванченко І.В. Аналітичний огляд оновлених оцінок щодо перспектив розвитку вітроенергетики. Відновлювана енергетика. 2019. № 3(58). C. 42-47.

4. Europes onshore and offshore wind energy potential. An assessment of environmental and economic constraints. EEA Technical report. 2009. № 6. 90 p. [Електронний ресурс]. URL: https://www.eea.europa.eu/publications/europes-onshoreand-offshore-wind-energy-potential.

5. Cost-competitive renewable power generation: Potential across South East Europe. IRENA. 2017. 124 p.

6. Макаровский Е.Л., Зиныч В.О. Методика оценки ветрового энергетического потенциала. Збірник наукових праць «Проблеми охорони навколишнього природного середовища та екологічної безпеки». Харків. УкрНДІЕП. 2011. C. 211-228.

7. Природні зони України. Карта природних зон. [Електронний pecypc]. URL: https://school.hometask.com/prirodni-zoni-ukrayini-karta-prirodnix-zon/.

8. Інфографіка - розмір нормативної грошової оцінки 1 га с/г землі в усіх областях України на 2019 рік. [Електронний ресурc]. URL: https://agropolit.com/news/11019 -infografika--rozmir-normativno-groshovoyi-otsinki-1-ga-s-gzemli-v-usih-oblastyah-ukrayini-na-2019-rik. 


\section{REFERENCES}

1. Vetroenergetika Europe: ofitsialnyye itogi 2018 goda. [ Wind energy in Europe: official results of 2018]. [Electronic resource]

URL: https://elektrovesti.net/64642_vetroenergetika-evropyofitsialnye-itogi-2018-goda. [in Russian].

2. World Energy Investment Outlook. Special Report. OECD/IEA. 2014. 190 p. [Electronic resource]. URL: https://www.iea.org/publications/freepublications/publicati on/WEIO2014.pdf. [in English].

3. Kudria S.O., Tuchynskyi B.H., Ivanchenko I.V. Analitychnyi ohliad onovlenykh otsinok shchodo perspektyv rozvytku vitroenerhetyky.[Analytical review of the updated estimates of the prospects for the development of wind energy]. Vidnovluvana energetika. 2019. № 3(58). Pp. 42-47. [in Ukrainian].

4. Europes onshore and offshore wind energy potential. An assessment of environmental and economic constraints. EEA Technical report. 2009. № 6. 90 p. [Electronic resource]. URL: https://www.eea.europa.eu/publications/europes-onshoreand-offshore-wind-energy-potential. [in English].

5. Cost-competitive renewable power generation: Potential across South East Europe. IRENA. 2017. 124 p. [in English].

6. Makarovskij E.L., Zinych V.O. Metodika ocenki vetrovogo energeticheskogo potenciala. [Methodology for wind energy potential assessment]. Zbirnyk naukovykh prats «Problemy okhorony navkolyshnoho pryrodnoho seredovyshcha ta ekolohichnoi bezpeky». Kharkiv. UkrNDIEP. 2011. Pp. 211228. [in Russian].

7. Pryrodni zony Ukrainy. Karta pryrodnykh zon. [Electronic resource]. URL: https://school.hometask.com/prirodni-zoni-ukrayini-karta-prirodnix-zon/.

Ukrainian].

8. Infohrafika - rozmir normatyvnoi hroshovoi otsinky 1 ha s/h zemli $\mathrm{v}$ usikh oblastiakh Ukrainy na 2019 rik. [Infographic - the size of the regulatory monetary assessment of 1 ha of agricultural land in all regions of Ukraine for 2019] [Electronic resource]. URL: https://agropolit.com/news/11019infografika--rozmir-normativno-groshovoyi-otsinki-1-ga-s-gzemli-v-usih-oblastyah-ukrayini-na-2019-rik. [in Ukrainian].

\section{ПРИЧИНЫ И РЕЗУЛЬТАТЫ ПЕРЕСМОТРА ОЦЕНКИ ПОТЕНЦИАЛА ВЕТРОВЫХ ЭЛЕКТРОСТАНЦИЙ УКРАИНЫ}

С.А. Кудря ${ }^{1}$, чл.-кор. НАН Украины, докт. техн. наук, проф., Н.М. Мхитарян ${ }^{1}$, чл.-кор. НАН Украины, докт. техн. наук, проф., Б.Г. Тучинский ${ }^{1}$, канд. экон. наук, ст. науч. сотруд., А.А. Репкин ${ }^{2}$, глава наблюдательного совета
ООО Токмак Солар Энерджи, глава энергетической ассоциации «Українська воднева рада», И.В.Иванченко ${ }^{1}$, Е.В. Петренко ${ }^{1}$.

${ }^{1}$ Институт возобновляемой энергетики НАН Украины, 02094, ул. Г. Хоткевича, 20А, г. Киев, Украина. ${ }^{2}$ Общественный союз «Энергетическая ассоциация «Українська воднева рада», 01015, ул. Лаврская, 16, г. Киев, Украина.

Цель статьи - современная оиенка ветропотенциала Украины и перспектив развития ветроэнергетики. Спрос на электроэнергию имеет устойчивую тенденцию к росту, a предложение электроэнергии тепловых $u$ атомных электростанций ограничивается, главным образом, исчерпанием мировых запасов соответствующих энергоносителей и их неравномерным распределением между странами. Последнее создает политическую и экономиическую зависимость стран-импортеров энергоносителей от странэкспортеров энергоносителей. По прогнозу Международного энергетического агентства (IEA), в ЕС сумма инвестиций в ветроэнергетику в период 2014-2035 г2. составит 727 \$ млрд и будет самой высокой среди отраслей электроэнергетики - в 1.8 раза выше, чем в ТЭС и АЭС вместе (400 \$ млрд). За последнее время произошли существенные прогрессивные изменения количественных и качественных параметров генерачии электроэнергии ВЭС, а именно: удлинились лопасти ветровых электроустановок (ВЭУ), увеличились высоты башен ВЭУ. Исследования ветровых потоков показали, что вертикальные профили ветра фактически являются более чувствительныли к увеличению высоты над землей, чем предполагалось ранее. Кроме того, имеет место удвоение номинальной мощности ВЭУ, за счет чего уменьшаются как площчади покрытия ВEC, так и удельные расходы земли, изъятой из сельскохозяйственного пользования. Если в предыдущчих исследованиях пригодными для ВЭС считались только зоны Причерноморья и Приазовья, то в результате совместного действия перечисленных факторов значительные территории в других регионах Украины, ранее считавшиеся непригодными для размещения экономически эффективных ВЭС, перешли в категорию перспективных. В данной статье представлен географический подход $\kappa$ оценке ветропотенциала территории Украины. Этот подход значительно проще, требует значительно меньше затрат времени и средств, чем известные подходы. Библ. 6, табл. 4, рис. 8.

Ключевые слова: ветроэнергетика, технически достижсимый ветропотенциил, ветровая электростанциия, географический подход, зонирование, потенциал установленной мощности ВЭС. 